\title{
Editorial
}

\section{Managing the Microbial Activity in Food and Environmental Biotechnologies}

\author{
Dr. Olga Mutere, ${ }^{*}$
}

Dr. Biol., Senior Researcher, Deputy Director of the Institute of Microbiology \& Biotechnology, University of Latvia, 4 Kronvalda Blvd., Riga LV-1010, Latvia

The present issue embraces a broad spectrum of studies focused on applied or potentially applied aspects of microbiology and biotechnology. The papers reflect current scientific and technological investigations, which were performed in Latvia, Lithuania, Estonia, Sweden. Most of them are interdisciplinary, i.e., the expertises in microbiology, biochemistry, chemistry, veterinary, physics, engineering and other fields were applied. Probiotic lactic acid bacteria were tested for their antagonistic activity against mastitis causing bacteria. Three papers are focused on optimization of fermentation processes, using maize silage and acid whey in anaerobic processes, barley and pea fibers as well as lupine seeds for obtaining biologically active compounds. Wastewater treatment processes are represented by studies on the use of pink bark as a sorbent of nitroaromatic compounds; as well as biodegradation of phenols in pharmaceutical wastewaters and combination of nitrification and phosphorous accumulation processes. Newly developed inorganic carriers for solid state and submerged fermentations were tested, e.g., ceramic and alkali-activated beads. The review paper covers basic processes of phytoremediation with special emphasis on rhizoremediation and plant-microbe interactions in a plantassisted biodegradation in soils and treatment wetlands. Methodological aspects were discussed, in particular, the use of Fourier transform infrared spectroscopy in monitoring the sorption and degradation products in wastewaters. A new yeast based test system for rapid evaluation of the effects of various compounds on eukaryotic cells was suggested. Hopefully, you will find the papers included in this issue, interesting and useful.

\footnotetext{
*Address correspondence to this author at the Dr. Biol., Senior Researcher, Deputy Director of the Institute of Microbiology \& Biotechnology, University of Latvia, 4 Kronvalda Blvd., Riga LV-1010, Latvia; E-mails: olga.mutere@lu.lv, olga.muter@inbox.lv

${ }^{\S}$ Guest Editor.
}

(C) Olga Mutere; Licensee Bentham Open.

This is an open access article licensed under the terms of the Creative Commons Attribution Non-Commercial License (http://creativecommons.org/licenses/ by-nc/3.0/) which permits unrestricted, non-commercial use, distribution and reproduction in any medium, provided the work is properly cited. 